University of Nebraska - Lincoln

DigitalCommons@University of Nebraska - Lincoln

Faculty Publications from the Harold W. Manter Laboratory of Parasitology

7-1958

\title{
Some Observations on Rabies in Alaska, with Special Reference to Wild Canidae
}

\author{
Robert L. Rausch \\ University of Washington, rausch@uw.edu
}

Follow this and additional works at: https://digitalcommons.unl.edu/parasitologyfacpubs

Part of the Parasitology Commons

Rausch, Robert L., "Some Observations on Rabies in Alaska, with Special Reference to Wild Canidae" (1958). Faculty Publications from the Harold W. Manter Laboratory of Parasitology. 404.

https://digitalcommons.unl.edu/parasitologyfacpubs/404

This Article is brought to you for free and open access by the Parasitology, Harold W. Manter Laboratory of at DigitalCommons@University of Nebraska - Lincoln. It has been accepted for inclusion in Faculty Publications from the Harold W. Manter Laboratory of Parasitology by an authorized administrator of DigitalCommons@University of Nebraska - Lincoln. 


\section{SOME OBSERVATIONS ON RABIES IN ALASKA, WITH SPECIAL REFERENCE TO WILD CANIDAE}

\section{Robert Rausch}

Zoonotic Disease Section, Arctic Health Research Center, Public Health Service, U.S. Department of Health, Education, and Welfare, Anchorage, Alaska

It is the purpose of this paper to summarize available information on outbreaks of rabies recorded in canine animals in Alaska over a 9-year period (1949-57), and to discuss some problems relating to the natural history of rabies in high boreal regions.

Four species of wild canids occur in Alaska: (1) coyotes, Canis latrans, are found throughout most of the forested interior; (2) wolves, Canis lupus, are distributed over the entire mainland, excepting those regions where wild ruminants are absent; (3) arctic foxes, Alopex lagopus, are restricted in their distribution on the mainland to the tundra zone of northern and western Alaska-they also inhabit islands in the Bering Sea (Nunivak, the Pribilofs, the St. Matthew Islands, and St. Lawrence), and have been introduced on many of the Aleutian Islands; (4) red foxes, Vulpes vulpes, are found over the entire mainland, and are indigenous on Kodiak, Unimak, and Nunivak Islands. They sometimes reach St. Lawrence Island by means of the pack ice, but do not occur on the other remote islands in the Bering Sea.

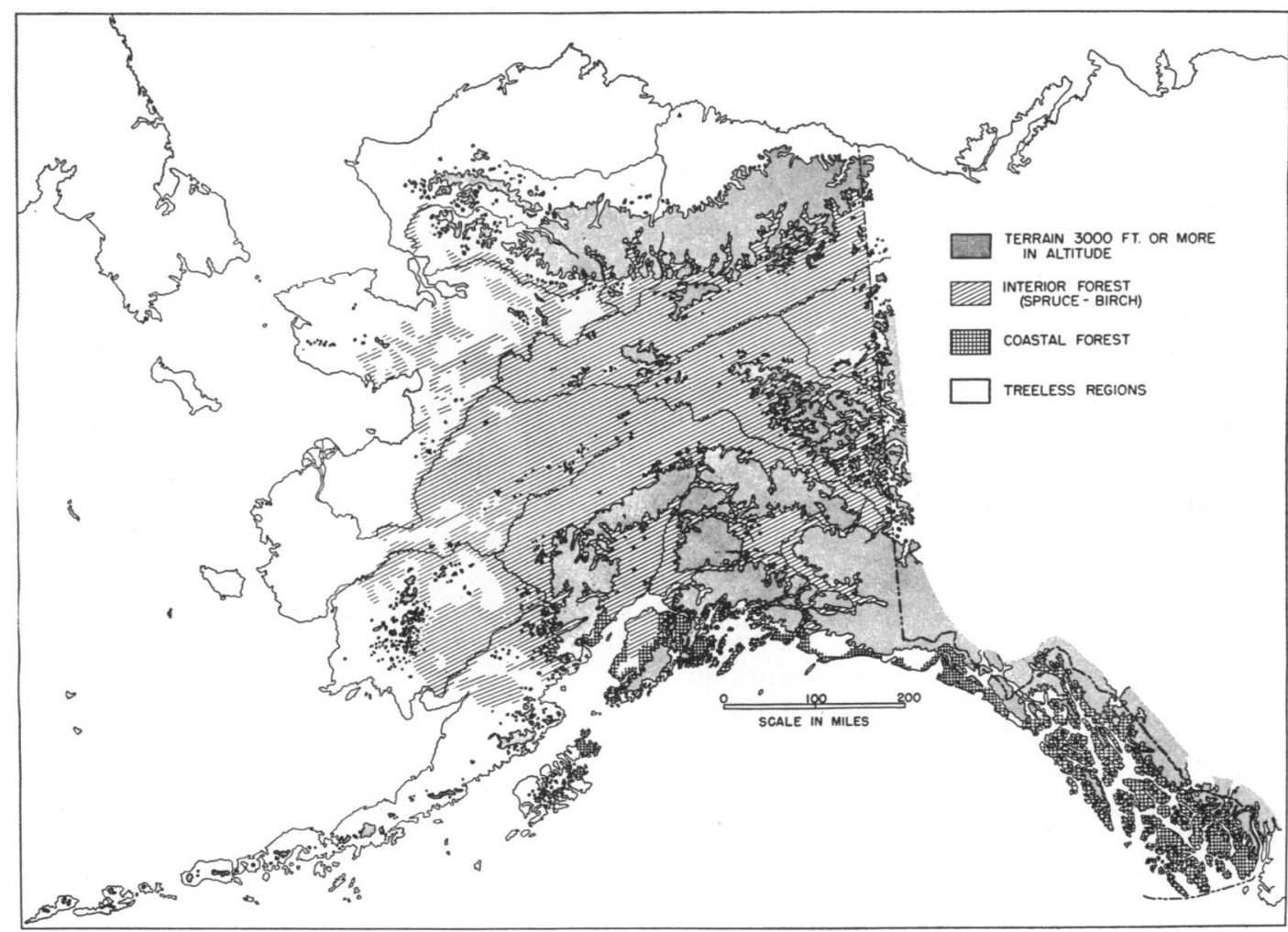

Fig. 1. Major biotic regions of Alaska. The treeless regions of northern and western Alaska are tundra; much of the Alaska Peninsula is grown to Alnus and other nonarborescent species. Treeless coastal areas east of the Kenai Peninsula represent glaciers. (Map compiled from various sources.) 


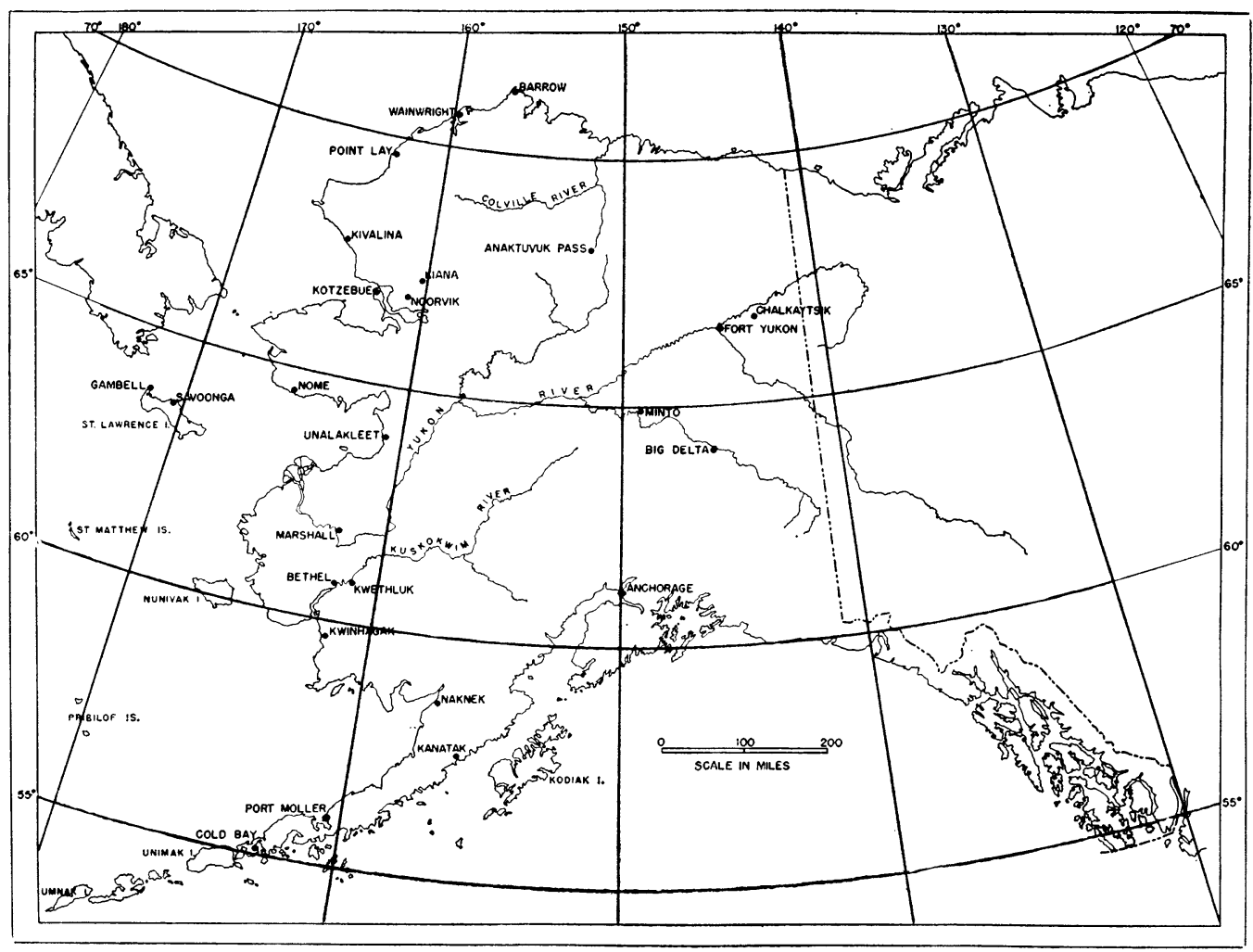

FIG. 2. Map of Alaska, with localities from which rabid animals have been recorded.

In addition to the wild canids, domesticated dogs are associated with human habitations throughout the Territory. Except in the largest towns, the dogs are kept exclusively for use as draft animals.

The distribution of the wild mammals mentioned in this paper can be related to the major biotic regions of Alaska, shown in Fig. 1. The more important place names are indicated in Fig. 2. Southeastern Alaska has not been included in this consideration.

During the time of the observations reported herein, rabies has been recorded frequently in foxes (both Alopex and Vulpes), only twice in wolves, and not at all in coyotes. The $a$ priori diagnosis of rabies seems generally to be justified whenever inhabited places are invaded by wild canine animals manifesting aggressive behavior toward man and dogs. With the exception of a coyote from southern Alaska, rabies was confirmed by isolation of the virus from all canine animals showing this behavior that were obtained for study. In uninhabited regions, outbreaks of rabies have usually been detected through the finding of dead foxes. Without exception, rabies has been confirmed in all such foxes obtained from arctic Alaska. Two red foxes found dead on Kodiak Island were not rabid, however.

The possibility exists that animals affected by canine distemper may occasionally appear to be rabid. Helmboldt and Jungherr (1955) and Habermann, et al. (1958) reported that foxes having canine distemper sometimes show aggressive behavior resembling that of rabid animals. Canine distemper is enzootic in sledge dogs in some regions of Alaska, but its occurrence in wild canids has not been confirmed. In July 1952, following an epizootic outbreak of distemper in sledge dogs along the arctic coast during the previous winter, distemper appeared in dogs at Anaktuvuk Pass, about 250 miles to 
the south. Although it is believed that the disease might have been transmitted through wild canids to this locality (Reinhard, et al., 1955), no evidence for this was obtained. Another epizootic outbreak of distemper occurred in the lower Kuskokwim River region during the winter of 1957-58, but again there was nothing to indicate that the wild canids were affected.

\section{ACKNOWLEDGMENTS}

Much of the information included in this report was obtained through the support of the Arctic Research Laboratory, Office of Naval Research, at Point Barrow; Max C. Brewer, present director of the Laboratory, has provided specimens and information. Personnel of the U.S. Fish and Wildlife Service have made available many specimens of mammals since the inception of this work in 1949. Most of the inoculations of animals to demonstrate rabies virus were performed through the generous cooperation of Robert E. Kissling, Virus and Rickettsia Section, Communicable Disease Center, Public Health Service, Montgomery, Alabama. Frank P. Pauls, director of the South-Central Laboratory, Alaska Department of Health, made available data on rabid animals submitted to his laboratory. E. L. Schiller, now at the School of Public Health, Johns Hopkins University, assisted in field work on St. Lawrence Island from 1950 to 1955. Francis H. Fay, Zoonotic Disease Section, Arctic Health Research Center, assisted in this work and provided information and specimens derived from his field work on St. Lawrence Island since 1952. Francis S. L. Williamson assisted with this investigation in the laboratory. Mrs. Reggie V. Rausch prepared the illustrative material. Many individuals have contributed specimens of mammals; in this connection, the efforts of the Eskimos at Anaktuvuk Pass since 1949 have been especially important. I wish to espress sincere appreciation for all such support.

\section{Historical Background}

That rabies is a common disease of wild canids in Alaska has become evident only in recent years, during which improved facilities for transportation and communication have made it much easier to obtain suitable specimens and information from all parts of the Territory.

The earliest record of a rabies-like disease in Alaska appears to be that of Nelson (1887: 237), who stated that such a disease was known in sledge dogs "... f from Greenland to Bering Sea." From his description, the disease observed was clinically identical with rabies. A. Murie (1944) received information on an outbreak of rabies among foxes along the lower Kuskokwim River in the spring of 1907. In April and May 1915, Ferenbaugh (1916) diagnosed rabies in foxes in the region of the Yukon delta. Williams (1949) summarized information on rabies in Alaska and reported the epizootic outbreaks of 1945-47. A few isolated cases have been reported more recently (Rausch, 1951, 1953; Schiller and Rausch, 1956).

Rabies has been rarely diagnosed in man in Alaska. Ferenbaugh (op. cit.) cited a case following an attack by a sledge dog near Candle during February 1914. In 1942, an old Eskimo died apparently of rabies on March 14; on January 27, he had been attacked and severely wounded by a wolf in his camp about 10 miles north of Noorvik (Newcomb, unpublished data). A third case was diagnosed clinically at the Barrow hospital in May 1943; at that time the presence of the disease in dogs in the village was confirmed.

\section{Methods}

Whenever suspected animals could be obtained, the diagnosis of rabies was made only by the isolation of the virus. Most of this work was performed at the laboratory of the Virus and Rickettsia Section, Communicable Disease Center, in Alabama, to which brain tissue was sent for the inoculation of experimental animals. Such tissues were collected at the laboratory in Anchorage and preserved in 50-per-cent glycerin. A portion of each brain was also preserved in 10-per-cent Formalin for histological examination. Routine microscopic examina- 
tions were not made, since it has been found that the typical inclusion bodies of rabies (Negri bodies) usually are not visible in the brains of rabid animals in Alaska.

\section{Records of Rabid Animals (1949-57)}

Records of rabies in canine animals, including dogs, are listed below by year. The specific identity of a few foxes, not submitted to me, was not determined. The diagnosis of rabies was confirmed by the inoculation of experimental animals for all canids designated below as rabid. Unconfirmed reports of outbreaks of rabies have also been included. It is known that rabid foxes entering villages have sometimes been killed and not reported; consequently, the records presented here are incomplete. All records are shown, by species, on outline maps (Figs. 3-7).

1949. A rabid dog was killed during January at Fort Yukon. Reports were received of arctic foxes attacking dogs in the villages of Barrow and Point Lay during the fall (Fig. 3 ).

1950. A rabid dog was killed in Anchorage in February. Despite the presence of a very large,

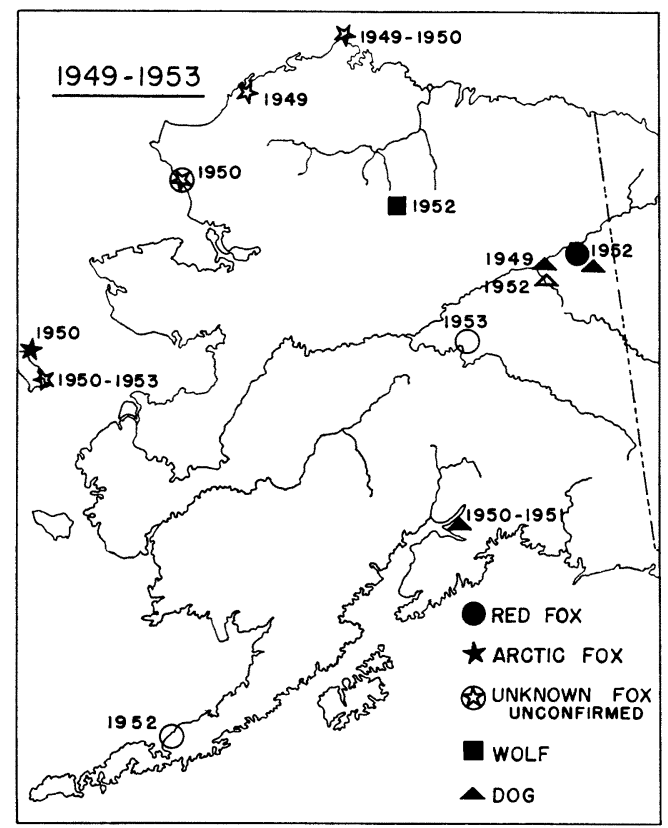

Fig. 3. Records of rabid animals in Alaska, 194953. Hollow symbols represent animals considered to be rabid; the diagnosis was not confirmed in these by inoculations of laboratory animals. uncontrolled population of dogs, no other cases were detected here. Rabies was reported in arctic foxes and dogs in the vicinity of Barrow during January, and a similar report was received in February from Savoonga; no specimens were available. I went to St. Lawrence Island in April to procure additional information, and while there, an arctic fox, later found to be rabid, was shot when it entered the village of Gambell on May 4. I examined several dogs manifesting clinical signs of rabies; these animals were destroyed. An unidentified fox attacked dogs in Kivalina during December, but was not preserved for study (Fig. 3 ).

1951. A rabid dog was killed in Anchorage on February 19; again this was an isolated case. Rabies was not reported among wild canids during 1951 (Fig. 3).

1952. A rabid wolf was shot on May 4, when it attacked dogs in an Eskimo camp at Anaktuvuk Pass. During the late summer and early fall, a number of apparently rabid red foxes invaded Chalkaytsik and attacked dogs. At least 12 foxes were killed between August and November. Three foxes and one dog were subjected to laboratory studies and proved to be rabid. Red foxes were reported to have attacked dogs near Port Moller during late November. A dog at Fort Yukon was reported to have shown clinical signs of rabies in December (Fig. 3).

1953. During June, F. H. Fay found an arctic fox, presumably dead of rabies, at Siknik, St. Lawrence Island. A red fox was killed at Minto after it had attacked dogs and attempted to enter a dwelling. Neither animal was preserved (Fig. 3).

1954. A rabid red fox was killed at Kwethluk on February 26. On the same day, a rabid arctic fox was killed after attacking dogs in Nome. During April and May, a rather extensive outbreak of rabies occurred in foxes along the arctic coast. A rabid arctic fox was killed in Barrow on April 17, after it had bitten eight sledge dogs. Three arctic foxes showing behavior typical of rabid animals attacked dogs in Wainwright at about the same time; the one obtained was rabid, and at least one dog was killed after it showed clinical signs of rabies. At this time, George Thiele, a pilot at Barrow, made some interesting observations. Arctic foxes are easily observed from small planes flying at low altitudes; they always show great fear of such planes and attempt to escape by running away. During April, Mr. Thiele observed that foxes south of Wainwright often behaved in an unusual manner, i.e., they made no attempt to run away, but stood their ground and showed signs of aggressiveness. Such behavior was noted in eight or ten foxes, and it seems probable that these animals were rabid.

Three rabid animals were submitted to this laboratory from Kotzebue: a red fox attacked dogs on March 27 and was killed; one of these dogs was shot on April 16, when it showed clinical signs of rabies; an arctic fox was killed on April 30. A rabid dog was killed in Unalakleet on April 16. 
During March, several red foxes were destroyed when they attacked dogs in the Aleut village of Kanatak. After the snow melted in the late spring, other dead foxes were found, but material was not saved for examination. At least one dog at Kanatak later showed clinical signs of rabies. A rabid red fox was killed on April 25 at Naknek, in the same region.

During May and June, arctic foxes attacked dogs in Savoonga, St. Lawrence Island, and some of the latter eventually developed clinical signs of rabies. Several Eskimos were attacked by arctic foxes near Gambell during June, and dogs in this village were reported rabid. F. H. Fay found two dead foxes in early June, one near Gambell and one near Singikhpuk. At least seven more dead foxes were found by Eskimos at Poowooliak, Moghoweyik River, and Kaghoopalik, in the western part of the island. All were in the winter pelage. Other foxes, which might also have died during the colder months, were found in July and August. Arctic foxes again invaded Savoonga during September. In late November and early December, I traveled over the full length of the island by dog team, and from two to five recently dead foxes were found daily on the trail. Since no effort was made to search for such animals, extensive mortality was indicated. Unfortunately, we were unable to carry the animals with us, and so none was preserved. However, since rabies appears to be endemic on St. Lawrence Island, and lacking any evidence of distemper among the dogs at that time, I regarded rabies as the cause of death in these animals.

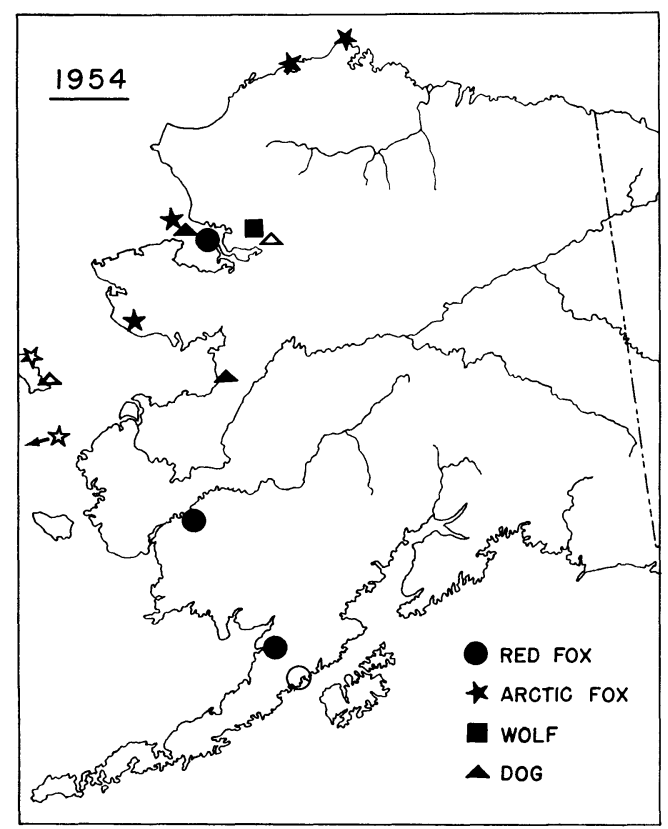

FIG. 4. Records of rabid animals in Alaska, 1954.

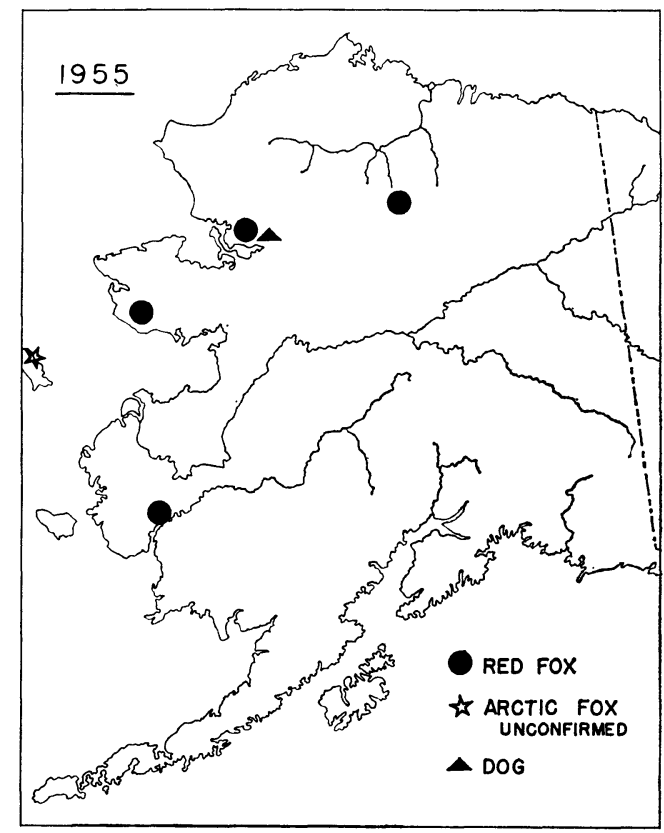

FIG. 5. Records of rabid animals in Alaska, 1955.

Over a 5-week period during August and September, I found several dead arctic foxes on St. Matthew Island. These were in winter pelage, and decomposed to the extent that the cause of death could not be determined. Since voles (Microtus abbreviatus) were extremely abundant, starvation could hardly have been the cause of death. There was no evidence of any disease among the living foxes observed or collected during this time.

A rabid wolf was shot in Kiana on October 26, after it had bitten about 20 dogs. Six of these dogs developed clinical signs of rabies within the next 3 weeks and were destroyed. No dogs were subjected to laboratory investigation (Fig. 4).

1955. A rabid red fox was killed on March 4, when it attacked dogs near Nome; another was found dead at Anaktuvuk Pass the same month. Red foxes attacked dogs in Bethel on July 29 and 30; one killed in August was proved rabid. A rabid red fox was killed while attacking dogs in Noorvik about mid-October; one of the latter became rabid and was killed on November 12, when it attempted to bite its owner. Three or four arctic foxes regarded as rabid were reported from Savoonga during the fall, but none was preserved for study (Fig. 5).

1596. A rabid red fox was killed on February 6, while attacking a resident of Marshall. Another was killed on February 11, as it was fighting dogs at Cold Bay. On April 16, flying in a small plane a few miles northeast of Kotzebue, Robert Burkholder, U.S. Fish and Wildlife Service, found two obviously abnormal red foxes, his attention having 


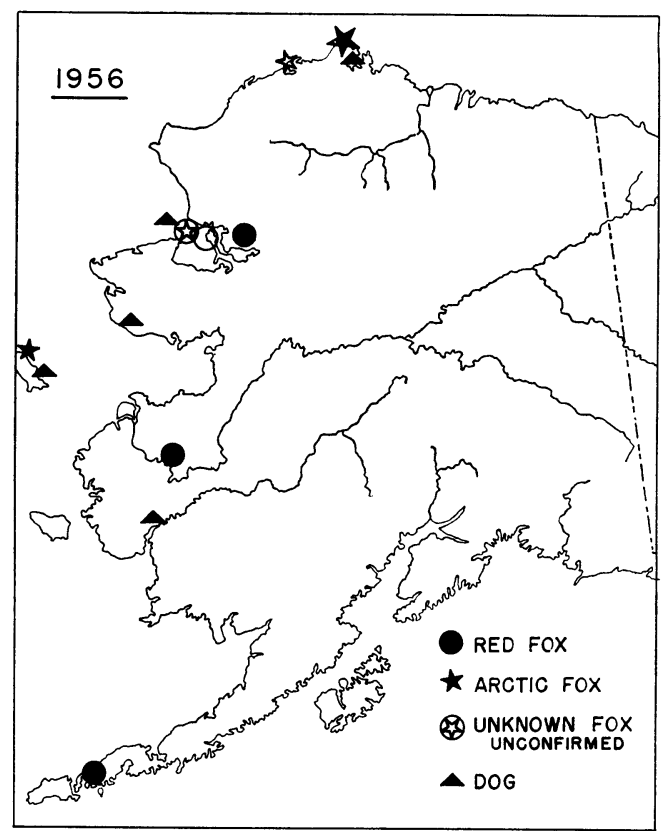

FIG. 6. Records of rabid animals in Alaska, 1956.

been brought to them by their erratic trails in the snow. The first was seen in a moribund condition at the end of one trail. Later in the day, upon Mr. Burkholder's return flight, this animal was dead; landing in the area was impossible, however. The second fox, dead when found, was secured and proved to be rabid. A rabid dog was shot in Bethel on April 27.

During the fall, an outbreak of rabies took place along the Arctic coast. Many arctic foxes moved into the area of a large construction camp near Point Barrow during September, apparently attracted by refuse and the food proffered them by the local personnel. By mid-October, it was estimated that about 125 foxes ranged in the camp area. The first signs of the disease were noted on September 24, when a worker was attacked by a fox. This animal was killed and found to be rabid, as were five others killed during October and early November. Although foxes were uncommon around the village of Barrow, a few miles down the coast, signs of rabies were noted there in dogs during the same period; an effort was made to destroy unrestrained dogs, and 58 of these animals had been killed by late November. Some of the foxes gradually moved northward onto the sea ice, but many remained in the camp. In order to ease the problem, it seemed advisable to destroy as many of the foxes as possible; 56 were trapped over a 4-day period (November 21-24). These, including one red fox, were made available to this laboratory for study. It was demonstrated that 5 of the arctic foxes ( 9 per cent of the total) were rabid.
The outbreak subsided following the elimination of stray dogs and foxes in the area. Rabid foxes attacked dogs in Wainwright during the same period of time. However, few foxes were involved, and no serious problem resulted (Fig. 6).

1957. On January 26, F. H. Fay found a rabid arctic fox dead at Tapphook, St. Lawrence Island. A rabid arctic fox was killed on February 7 at Barrow, and another was killed by dogs when it tried to enter a dwelling in Kiana on March 28. A rabid red fox was destroyed during November at Kwinhagak. An arctic fox showing clinical signs of rabies was shot on St. Lawrence Island during December. This animal has not been subjected to diagnostic tests, but rabies in a dog from this area has been recently confirmed (Fig. 7).

\section{Notes on the Natural History of Rabies in Alaskan Mammals}

\section{Alopex lagopus}

During the period 1949-57, rabies was confirmed (by isolation of the virus) in 19 arctic foxes. Many more animals that could not be obtained for laboratory investigation are known to have shown clinical signs of rabies. Rabies is a common disease of the arctic fox throughout Alaska.

The Arctic coastal plain.-The tundra biome, to which the arctic fox is mainly

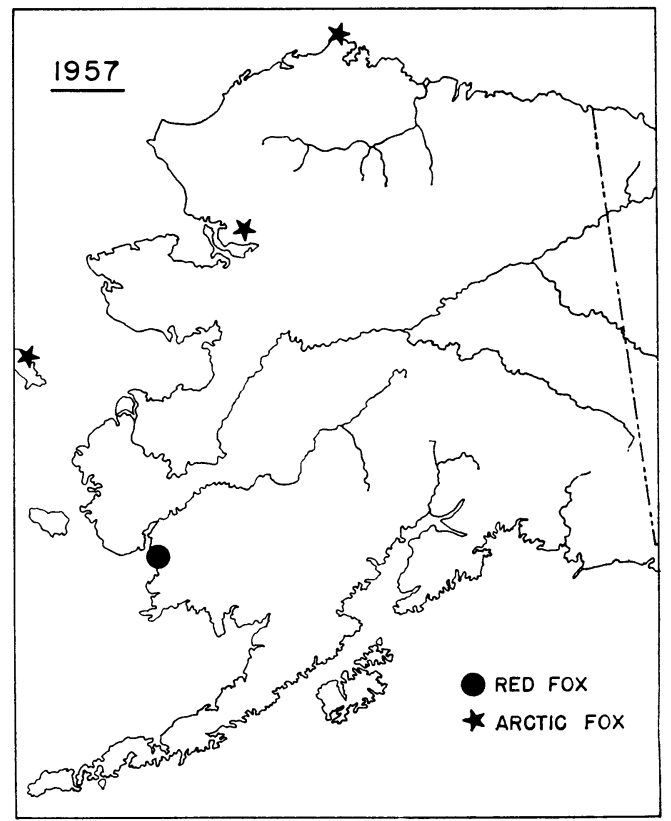

Fig. 7. Records of rabid animals in Alaska, 1957. 
restricted in its distribution, is characterized by a fauna consisting of relatively few species of vertebrates, some of which fluctuate extremely in numbers. On the Arctic coastal plain of northern Alaska, the abundance of arctic foxes appears to be closely correlated with the population density of the brown lemming, Lemmus sibiricus. Fluctuations in the populations of this lemming show a cyclic pattern, with an average periodicity of $3-4$ years. Brown lemmings were abundant in the region of Point Barrow in the years 1946, 1949, 1952-53, and 1956 (Rausch, 1950; Pitelka, et al., 1955; Thompson, 1955). Although high densities of lemmings are usually not contemporaneous over the entire coastal plain, they nevertheless are of considerable areal extent.

Following declines, most of which are abrupt, in the populations of lemmings, arctic foxes may become extraordinarily numerous along the Arctic coast during the fall and early winter. At such times, red foxes are usually also present, but they are relatively few. Arctic foxes were abundant in the region of Point Barrow in 1949, 1953, 1954, and 1956, when, in the fall, the greatest concentration was seen. Unconfirmed rabies was reported in foxes at Barrow in the fall of 1949. I secured rabid foxes in 1954 and 1956 , and one also in 1957, when foxes were scarce. Farther down the coast, arctic foxes were unusually numerous around Wainwright during the fall of 1954. Animals showing clinical signs of rabies were observed during the preceding spring, but there was no fall evidence of the disease.

From the vicinity of Point Lay, about 100 miles down the coast from Wainwright, and as far south as the mouth of the Kuskokwim River, a vole (Microtus oeconomus) has been the predominant microtine rodent of the tundra zone. Lemmus is also present, but its populations have remained at a low density during the time of this study. Voles were abundant around Point Lay in 1949 and 1952. The numerical status of the foxes was not determined, but rabid animals were reported only during the fall of 1949. Elsewhere in mainland Alaska, no information was obtained that served to correlate the abundance of arctic foxes with the occurrence of rabies.

St. Lawrence Island.-Annual observations on St. Lawrence Island were begun in 1950 by the staff of the Zoonotic Disease Section. Although minor fluctuations in the numbers of $M$. oeconomus may have gone unnoticed, it appears that these rodents increased until they attained the highest density observed during the summer of 1954 . From extensive field observations during November and December of 1954, it was evident that a severe reduction in numbers of voles had occurred during the early fall. In the following spring (1955), voles were still numerous only in the most favorable habitat. Surveys made by F. H. Fay during the summers of 1956 and 1957 indicated a generally low density, with some increase evident in 1957.

The trapping success of the Eskimos would seem to provide an index of changes in the population density of the arctic foxes on St. Lawrence Island. Data available for the village of Savoonga, obtained from the records of the Savoonga Native Store, are presented in Fig. 8. Unusual conditions of weather in the winter of 1948-49 led to the starvation of an estimated 2,000 reindeer (Rangifer tarandus). Although it cannot be confirmed, available information suggests that these carcasses served to attract and hold an unusually large number of foxes over the winter. A high productivity with good survival is indicated by the trapping results of the following year (1949-50). No figures were available for the 1950-51 season. The very low figure indicated for 1951-52 appears to be misleading, since, prior to the trapping season, many of the men from Savoonga were temporarily employed on a construction project; the resulting income was comparatively large, and there was less interest in trapping. Foxes were clearly numerous from the winter of $1952-53$ to the winter of 1954-55. The abrupt decline in the numbers of voles during the fall of 1954 undoubtedly affected the abundance of foxes in the following years, since voles are an important foodresource for the young while they are in 


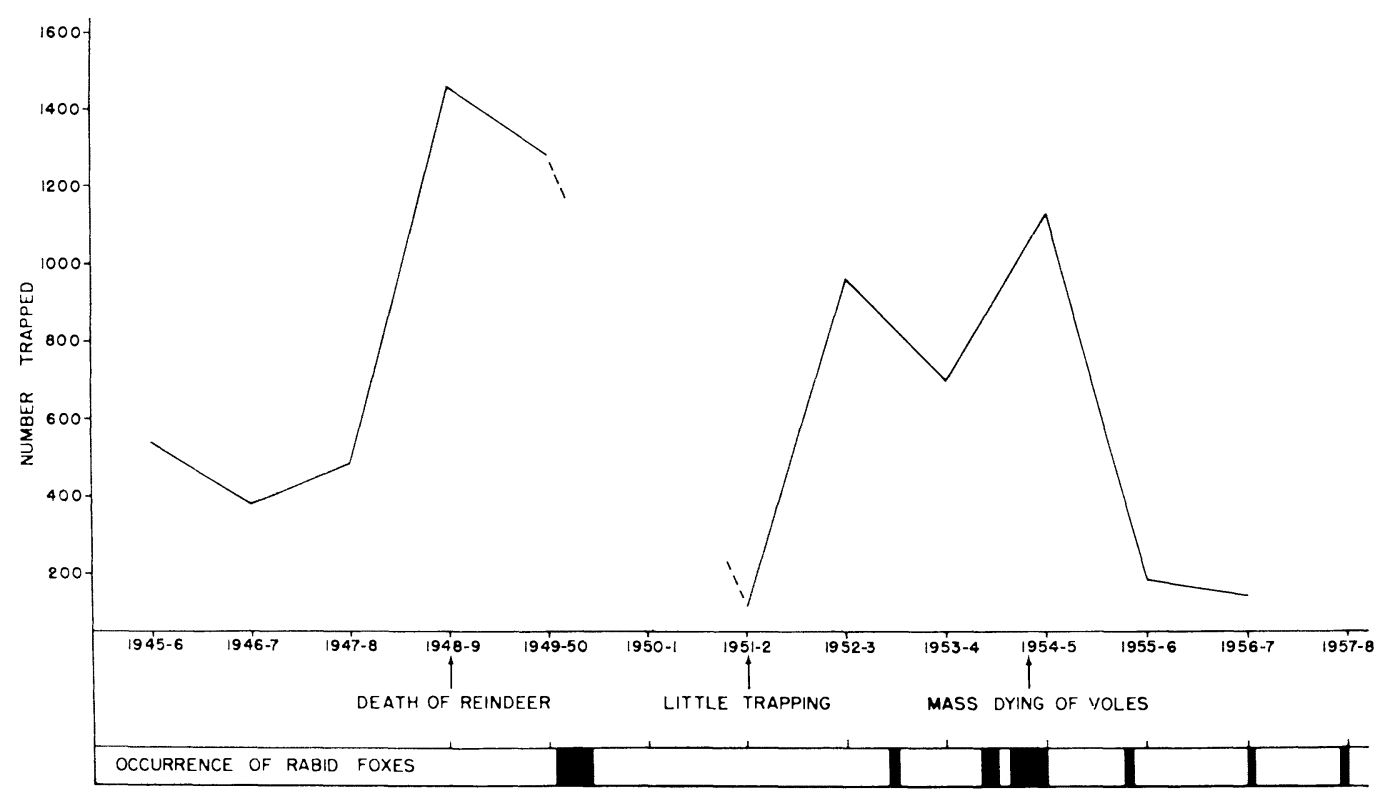

Fig. 8. Index of changes in population density of arctic foxes on St. Lawrence Island, as shown by annual trapping results of Eskimos from the village of Savoonga. Records of animals regarded as being rabid are indicated to the nearest month.

the burrow. Foxes were relatively abundant when voles attained their maximum density.

As may be seen from Fig. 8, rabies was recorded in foxes on St. Lawrence Island in 1950. This outbreak apparently did not assume epizootic proportions, although rabid animals were still present in the early spring. The outbreak of 1953-54 was much more extensive, and possibly caused a significant reduction in the numbers of foxes. There was evidence of rabies in foxes during the fall of 1955, but this was not confirmed. The cause of the great reduction in numbers of foxes during 1955-57 has not been ascertained. The disease certainly had some effect, but the scarcity of voles might have been much more significant. Rabies was recorded in a fox in January 1957, and a probably rabid animal was killed in December 1957. Both trapping results and field observations substantiated the conclusion that arctic foxes were relatively scarce during 1956-57.

\section{Vulpes vulpes}

Rabies was confirmed in 14 red foxes over the 9-year period. Clinical evidence indi- cated that many other animals, not secured for study, also were rabid.

The forested interior.-In interior Alaska, particularly in the spruce forest biome, predator-prey relationships are relatively complex, and observation is more difficult. In addition to several species of microtine rodents, snowshoe hares (Lepus americanus) and two species of ptarmigan (Lagopus lagopus and L. mutus) fluctuate in numbers, and may differ greatly in abundance from one region to another at any given time. Since red foxes utilize these and other species of animals as food, their population density could not be correlated with fluctuations in the population density of any one species.

Red foxes have been generally common in Alaska over the period under consideration. Because of their low fur value, they have been little trapped, and their numbers have not been much influenced by man. Information indicating significant changes in their numbers is lacking, except that they were unusually numerous in the central Brooks Range in 1955. During the preceding years snowshoe hares had gradually ex- 
tended their range northward in the riparian vegetation of the river bottoms here, attaining their northernmost limits and greatest density in 1955. At the same time, ptarmigan were abundant. Voles (Microtus miurus) had been common to abundant since at least 1949. Except for the finding of one red fox dead of rabies in 1955, there was no evidence of the disease in this region. Any major outbreak of rabies could hardly have escaped notice, since the Eskimos traverse this region continually for hunting and trapping and would have collected for me any dead or obviously diseased foxes. I found red foxes still common here in 1956 and 1957, during the spring. Ptarmigan were still abundant, but snowshoe hares were becoming increasingly scarce.

The Arctic coastal plain.-In the tundra zone of northern Alaska, red foxes are commonly found in the somewhat broken country well inland. Following times of abundance of brown lemmings or voles, red foxes are usually seen along the Arctic coast. At such times, however, they are relatively few in proportion to the numbers of arctic foxes. In the tundra zone farther to the south, where different topographic conditions provide better habitat, red foxes are found along the coast of the Bering Sea. They have not been abundant anywhere in the tundra zone, however, and rabid animals have been recorded only infrequently.

Kodiak Island.-Since at least 1953, Kodiak Island has sustained a generally high population of red foxes. The animals frequent the beaches, where they feed at low tide, and often may be seen in numbers. In May 1957, during a 2-week period, I sometimes had ten or more red foxes in view at one time around the south end of the island. Their feeding habits ensure frequent contact among themselves, and this would seem to favor the transmission of disease. Rabies has not been recorded from Kodiak Island.

\section{Canis lupus}

Rabies has been confirmed in only two wolves during the time of these observations. No additional animals suspected of being rabid have been reported.
Little is known about the natural fluctuations in the numbers of wolves in Alaska. According to A. Murie (op. cit.), wolves were generally numerous from about 1927 through the early 1940's. Cowan (1949) stated that wolves had been approaching a cyclic peak over much of northwestern North America during the 1940's. Of the wild canids, wolves have been the most adversely affected by man, principally through widespread predator control and bountyhunting which have decimated these animals in some regions of Alaska.

The central Brooks Range.-In the Anaktuvuk Pass region, the trapping success of the Eskimos, who derive most of their income from hunting wolves, has indicated rather major fluctuations in numbers. Approximately 150 wolves were taken during the winter of 1942-43. Descriptions provided by the Eskimos leave little doubt that rabid wolves were observed in the Anaktuvuk Pass region in 1945. At least five apparently rabid wolves were killed; one of these had attacked an Eskimo hunter, and one was shot as it pursued another wolf. In addition, Williams (op. cit.) reported rabies in a wolf killed in December 1945, at Central, Alaska. Following the maximum density of 1942-45, from 20 to 50 wolves were killed annually by the Eskimos until the winter of 1951-52, when the Eskimos killed about 160 and about 200 more were destroyed by the U.S. Fish and Wildlife Service (Rausch, 1953). In 1952, a rabid wolf was shot as it attacked dogs in a camp at Anaktuvuk Pass, but no others were observed. Since 1951-52, wolves have been scarce in this region. The natural fluctuations in numbers here may be much affected by an increasing amount of bountyhunting from small planes.

\section{Canis familiaris}

Rabies was confirmed in eight dogs. Others were known to have developed clinical signs of rabies after having been attacked by foxes, some of which were proved to be rabid. Except for the two rabid dogs from Anchorage, nearly all cases of rabies in dogs were known to have followed attacks by wild canids. 


\section{Discussion}

\section{Rabies and Mammalian Populations}

Canine populations.-Cowan (op. cit.) suggested that rabies may be an important factor in the natural control of wild canine populations. He attributed an abrupt decline in a red fox population in the Mackenzie delta region during the winter of $1944-45$ to a disease clinically identical with rabies. He was unable to obtain any specimens for laboratory study at the time. However, the presence of rabies in this region was confirmed in March 1947, when a dog and a wolf were obtained from Aklavik (Plummer, 1947a ). Cowan was unable to determine that the population density of wolves had been affected by the disease. Freuchen (1935) regarded rabies as an important cause of declines in the populations of arctic foxes in eastern Arctic Canada.

Elton (1931, 1942) was primarily concerned with the relationship between disease and population cycles in the arctic fox. Unfortunately, in connection with his work, it was impossible to make laboratory diagnoses of any disease. Elton (1942:476) recognized a disease which had much in common with rabies, but which ". . . is not ordinary rabies and is usually quite different from ordinary dog distemper." Elton concluded earlier (1931:691), from information derived from questionnaires sent to traders and others in the Canadian arctic, that "disastrous epidemics occur periodically among the sledge dogs of the Canadian arctic," and stated further: "A similar and probably identical disease occurs among arctic (white) foxes in the North, and appears to be associated with the periodic cycle in numbers of the foxes." In his comprehensive work (1942), Elton concluded that cycles in canine populations were not caused by disease.

During the last 9 years, outbreaks of rabies in Alaskan canids have sometimes occurred at times of high population density. This was noted in arctic foxes at Point Barrow in 1954 and 1956. Rabies was reported but not confirmed in arctic foxes in 1949. No rabid animals, or animals suspected of being rabid, were recorded in this region in 1953 . According to reports, rabies affected wolves at the time of the high population density of 1943-45; the presence of the disease was confirmed at the time of the next peak, in 1951-52. Rabies was diagnosed also in arctic foxes at times of low population density (e.g., Barrow, 1957; St. Lawrence Island, 1957).

Knowledge is insufficient at the present time to allow the conclusion that rabies is important in the control of populations of canine animals in high boreal regions. Such sometimes may be the case, but additional investigation is needed.

Most cases of rabies in Alaska have been recorded during the colder months. During this period, and up to and including the breeding time of early spring, arctic foxes move about and often congregate around any abundant supply of food. Concentrations following declines in lemming populations occur in the fall. The increased contact among these animals probably favors the transmission of rabies. No other factors influencing the seasonal occurrence of rabies have been defined.

In some years, widely separated outbreaks of rabies evidently had independent origins. Large-scale, progressively spreading outbreaks, such as that in Alberta described by Ballantyne and O'Donoghue (1954), have not been observed in Alaska. Unfortunately, very little is known about the distances traveled by rabid animals. Gier (1948:150) stated: "The little that is known of rabid fox behavior indicates that such animals probably do not travel far after they develop the disease, so probably the rapid spread of the disease cannot be attributed to promiscuous distribution by a few individuals." One observation in Alaska is of interest. A wolf, mentioned earlier, attacked an Eskimo about 10 miles above Noorvik at approximately 5:00 P.M. on January 27, 1942; this animal was killed very early in the morning of January 28 , while attacking dogs in the village of Kiana, about 15 miles upstream from the first locality. The wolf was recognized by knife wounds inflicted by the Eskimo on the previous day. 
The origin of outbreaks of rabies on isolated islands in Arctic waters is difficult to determine. Such islands would seem to provide unusually favorable conditions for the investigation of the natural history of this disease. On such islands, outbreaks presumably could originate in only 3 ways: (1) the disease might remain enzootic in resident foxes; (2) it might be introduced by immigrating foxes; (3) it might be enzootic in mammals of other species, from which it could then be transmitted to the foxes.

Assuming that rabies invariably terminates fatally in foxes, the disease could hardly be maintained within a restricted population of small size. It is known that foxes immigrate to certain islands in the Bering Sea via the pack ice from the north (Preble and McAtee, 1923; O. J. Murie, 1936). Such foxes might introduce rabies, although there is no evidence for this. Nothing is known at the present time about the natural occurrence of rabies in populations of the common small mammals (microtine rodents and shrews), but the possibility exists that some of these may serve as a reservoir of infection from which the disease is transmitted to canine animals.

Microtine populations.-The mass dying of microtine rodents, particularly lemmings, is usually followed by the disappearance of arctic foxes, which were dependent upon them for food. The apparent relationship between the dying of the lemmings and the occurrence of a rabies-like disease in foxes has been noted in Arctic Canada (Elton, 1931). With the qualification that disease of lemmings might be transmissible to other animals, Elton stated (ibid.: 689): “This opens up the possibility that the white fox disease is not only caused by the condition of the fox, but may even be derived directly from lemming epidemics." Elton (1942) gave little consideration to this possibility in his later work.

There is no information at the present time to suggest that lemmings or other microtine rodents have any importance per se in the causality of outbreaks of rabies in arctic foxes. Following mass dying of lemmings, the foxes migrate, and conditions then favor the spread of rabies among them. Regarding the "mad" foxes observed in some years in northern West Greenland, Braestrup (1941: 83) stated: "Thus it is probable that this disease, which is transmissible to dogs, is brought to Greenland by migrating foxes, in accordance with the fact that Arctic Foxes are most liable to this disease at times of lemming minima."

Rabies in other mammals.-Excepting man, rabies has been recorded in Alaska only from canine animals. In recent years lynxes (Felis lynx) have invaded settlements, including Anchorage and Fairbanks. The four animals subjected to investigation were not rabid.

Workers in wildlife management have expressed some concern that wild ruminants, especially deer (Rangifer tarandus and Alces alces) might be infected by rabid wolves or foxes. Although this has not been known to occur in Alaska, rabies was diagnosed in a caribou from the Northwest Territories (Ballantyne and O'Donoghue, op. cit.). Sdobnikov (1935) reported the infection of domestic reindeer ( $R$. tarandus) by foxes in northeastern Siberia. It is possible that such closely herded animals might be more vulnerable to the attacks of rabid animals than are the wild ones.

Ballantyne and O'Donoghue (op. cit.) reported rabies in a weasel (presumably Mustela erminea) in Alberta, and Freuchen (op. cit.) stated that ermines are sometimes infected in eastern Arctic Canada. Such animals might introduce the virus among the smaller mammals upon which they are known to prey.

Bats have a limited geographical range in Alaska. According to Miller and Kellogg (1955), Myotis lucifugus is found from the archipelago of southern Alaska southward. However, I have collected these bats on the Kenai Peninsula, at Anchorage, and on Kodiak Island. No effort has been made to find the virus of rabies in these animals. Their distribution is so restricted, and they are so uncommon, that it appears unlikely that they could have any important part in the epizootiology of rabies in Alaska. 


\section{Rabies in High Boreal Regions}

A rabies-like disease of canine animals has long been known to occur in arctic and subarctic regions. Early records of this disease in Canada have been discussed by Elton (1942), and Braestrup (op. cit.) has mentioned its occurrence in Greenland. Elton (ibid.:481) also reviewed some records of this disease in Alaska and Siberia. A survey of the Soviet literature is not included in the present paper.

"Arctic dog disease" is recognized to have important epizootiological and clinical characteristics in common with rabies. However, the lack of any evidence that the disease is transmissible to man has apparently been the primary reason that Elton and other workers have regarded it as being distinct from rabies. Rabies apparently has never been diagnosed in man in Greenland (Braestrup, op . cit.). Wells (1957) pointed out that the extensive records available for Arctic Canada list no human deaths from rabies. The aforementioned three cases of rabies in man in Alaska were diagnosed by clinical signs only.

The clarification of the problem has been delayed by the lack of laboratory investigations of the etiologic agent. As early as 1906, Hjortlund diagnosed rabies in canine animals in Greenland (Braestrup, op. cit.), basing his conclusions upon results obtained from the inoculation of experimental animals. Because there was no record of rabies having been transmitted to man in Greenland, and this fact could not adequately be explained, Hjortlund's findings were generally discredited. Baashuus-Jensen (1935) was especially critical of Hjortlund's conclusions and attempted to present evidence that the disease was caused by nutritional deficiency.

In the report of the Fifth Thule Expedition to Arctic Canada (1921-24), Freuchen (op.cit.:137) stated: "There is no doubt that quite another cause of variation in the number of foxes is disease. Beyond comparison, rabies is the most common, and it seems to attack wolves, ermines, and foxes. ..." In Canada, Plummer (1947) first demonstrated
Negri bodies in the brains of experimental animals inoculated with a suspension of brain tissue taken from a dog and an arctic fox obtained about 400 miles north of Fort Churchill. In a second report (Plummer, 1947a), the isolation of rabies virus from canine animals from Aklavik and Frobisher Bay was reported. In his discussion, Plummer (ibid.:334) stated: "The question still remains as to whether Arctic or Northern Dog disease is a combination of a number of different conditions or whether the virus of rabies is the only cause."

On the basis of clinical signs, Ferenbaugh (op. cit.) diagnosed rabies in Alaskan foxes in 1915. A diagnosis based upon laboratory studies apparently was not made until 1945 (Williams, op. cit.). In early 1949, in collaboration with Frank P. Pauls, Dr. L. T. Giltner, Bureau of Animal Industry, U.S. Department of Agriculture, undertook a detailed study of the virus isolated from the brain of a rabid dog killed at Fort Yukon. In order to test the pathogenicity of the virus in white mice, six groups consisting of six mice each were vaccinated against rabies by means of a commercial vaccine. Six groups of equal size were retained as controls. A suspension of virus was prepared from the brains of mice that had been infected with material from the dog. Dilutions of the suspension, ranging from $10^{1}$ to $10^{6}$, were prepared. Each mouse of the two groups recived $0.03 \mathrm{cc}$. of suspension intracerebrally, each group receiving a different dilution. All of the vaccinated animals survived. The mice in the first two control groups, receiving the $10^{1}$ and $10^{2}$ dilutions respectively, died; three mice in the third group, receiving the $10^{3}$ dilution, also died. The remainder survived. In a letter to Mr. Pauls, dated April 12, 1949, Dr. Giltner concluded: "These results indicate that the virus recovered from the ... dog is immunologically related to the rabies virus present in this country."

In my opinion, there is no longer any reason to doubt that the disease in question is rabies. No tangible differences between the etiological agents have been demonstrated. While it is generally true in high boreal re- 
gions that dogs showing the clinical signs of the disease are relatively nonaggressive, there are exceptions; some dogs have been known to attack their owners or others, as mentioned earlier in this paper. A rather wide range of behavioral patterns has been recorded in rabid dogs elsewhere; in the United States, nonaggressive animals frequently are reported to have "dumb rabies."

Plummer (1954) stated that the incubation period of rabies in canine animals in northern regions is but 4 to 5 days. I have not found this to be true. In several cases where the date of exposure was known in dogs attacked by rabid foxes, about three weeks passed before the onset of clinical signs of rabies. This falls within the limits of the incubation period known in dogs in the United States.

It is possible that the virus of rabies in high boreal regions is not so pathogenic for man as is the virus in the United States and elsewhere farther to the south. However, there is no evidence to support such an opinion. In Alaska, medical services in the remote regions have been relatively adequate for less than 10 years. Prior to this, the causes of death among the aboriginal people often were not determined, and cases of rabies easily could have gone unreported. In recent years, all persons known to have been injured by animals suspected of being rabid have received the preventive treatment for this disease.

Opportunities for human exposure to rabies in Arctic Alaska are really not great, despite the frequency with which rabid canids have been recorded. Among the canine animals, foxes are the species most commonly affected by rabies, and the clothing worn throughout the year is usually adequate to offer considerable protection against the bites of these animals. Rabid foxes are rather easily killed if they cannot be driven off. While most settlements have some unrestrained dogs, working dogs are generally kept chained. When such dogs are attacked by foxes in the village, or when they are bitten by foxes on the trail, they are kept under close surveillance. They are usually killed at the first signs of any illness.
Rabid wolves are capable of inflicting severe wounds, but such animals have been rarely seen. It is noteworthy that one of the two men known to have been attacked in Alaska by wolves that were considered rabid died of a disease clinically indistinguishable from rabies.

It is probable that human exposures to rabies are comparatively rare throughout the high boreal regions, in view of the uniformity of living conditions, clothing, etc., enforced by climatic conditions. Also, there is really a rather small probability that exposure to rabies in man will lead to infection and fatal disease. In this connection, Rhodes and van Rooyen (1953:412) make the following statement: "Even in the absence of antirabies treatment, the chance of contracting clinically evident disease after the bite of a proven rabid dog is only about 5 to 15 per cent."

\section{Control of Rabies in Alaska}

Most of the recorded outbreaks of rabies in Alaska have been of limited areal extent and have subsided without the institution of artificial controls.

The control of rabies in uninhabited wilderness areas is not practicable. It would be impossible, as well as biologically and economically unsound, to eliminate all of the mammals that might be involved in the natural cycle of rabies. In an effort to control an epizootic outbreak of rabies in Alberta, according to "a conservative summary of minimum total kills estimated from October, 1952, to March 1, 1954," 99,110 carnivores, representing nine species, were destroyed (Ballantyne and O'Donoghue, op. cit.). Epizootic rabies eventually abated in Alberta, but it cannot be established that the methods of control undertaken were responsible. Plummer (1954) and others have advocated the generalized reduction of wild mammalian populations as a method of controlling rabies. Such programs are very costly, and result in the destruction of many mammals of species not known to have any importance in the perpetuation of the disease. 
It is unrealistic to believe that rabies can be eliminated as a disease of wild canids in Alaska or in other arctic regions. Around the more remote settlements and villages, where outbreaks of rabies are most likely to affect the human population, adequate control of the disease could be achieved through the strict regulation of dogs combined with the local destruction of foxes when necessary. Sledge dogs should be restrained at all times, and any dogs in excess of actual needs should be destroyed. The aboriginal people are usually amenable to the destruction of uncontrolled or ownerless animals. The vaccination of all sledge dogs against rabies would be highly desirable, but there is no way at present to subvent the cost of such an annual program.

In urban areas, such as Anchorage or Fairbanks, the problem is similar to that existing in towns of similar size in the United States. Wild canids are absent or rare in such places, but unrestrained dogs are numerous. The popular attitude toward such dogs makes it very difficult to institute an appropriate program of dog control until an emergency arises. In 1951, following the diagnosis of rabies in a dog in Anchorage, more than 700 stray dogs were killed within a 3-month period. There was no legal means, however, by which dogs in the densely populated suburbs outside the limits of the city could be controlled. Even within the city any serious attempt to reduce the numbers of dogs was soon abandoned. It is doubtful that any effective program for regulating the numbers and movements of these animals will soon be put into effect. In such cities, the vaccination of all dogs would be economically feasible if it were required by law to do so.

Much remains to be learned about the natural history of rabies in wild canine populations. I believe that conditions in the arctic regions are especially favorable for the basic investigation of the epizootiology of this disease. Information derived from such studies could lead to more effective control of rabies in regions where it constitutes an important threat to man and domesticated animals.

\section{SUMmary}

Over a 9-year period (1949-57), 43 canine animals in Alaska were proved to be rabid: arctic fox, 19; red fox, 14; wolf, 2; dog, 8 . Many others of these, not secured for study, showed clinical signs characteristic of rabies. No evidence was obtained that any of these animals were affected by canine distemper or other diseases. The majority of outbreaks of rabies were recorded in the tundra zone of northern and western Alaska during the colder months. It was not determined that rabies is important as a natural control of wild canine populations. However, rabies was recorded in wolves only at a time of high population density. Outbreaks were sometimes observed along the Arctic coast among concentrations of arctic foxes which followed the mass dying of lemmings. Rabid canids also were recorded at times of low population density reported for arctic foxes.

Rabies was reported in wild canids in all years but 1951 . The most extensive outbreaks were recorded in 1954 and 1956. Except for two rabid dogs in Anchorage, about which nothing was known, nearly all dogs proved to be rabid or so regarded on the basis of clinical signs, had a history of contact with wild canids. In most cases, such dogs had been attacked by foxes. Evidence is presented to show that "arctic dog disease," long known to affect canine animals in high boreal regions, is in fact rabies. The differences recorded in the clinical manifestations of the disease in such regions are not regarded as significant. Although it is believed by some that the virus in northern regions is less pathogenic for man, this remains to be demonstrated. Three cases of rabies in man have been diagnosed clinically in Alaska-the first in 1914, the second and third in 1942 and 1943.

It appears that adequate control of rabies in Alaska could be achieved through the strict regulation of dogs combined with the local destruction of foxes when necessary. It would be desirable to vaccinate all dogs against rabies, but such a program is prevented at present by economic and legal considerations. 


\section{Literature Cited}

BaAshuus-Jensen, J. 1935. Arctic nervous diseases. Skand. Vet. Tidskr., 6:310-345.

Ballantyne, E. E. AND J. G. O’Donoghue. 1954. Rabies control in Alberta. J. Amer. Vet. Med. Assoc., 125(931):316-326.

Braestrup, F. W. 1941. A study on the arctic fox in Greenland/Immigrations, fluctuations in numbers based mainly on trading statistics. Medd. om Grønland, 131(4):1-101.

Cowan, IAN MCTAGgart. 1949. Rabies as a possible population control of arctic Canidae. J. Mammal., 30 (4):396-398.

Elton, Charles. 1931. Epidemics among sledge dogs in the Canadian arctic and their relation to disease in the arctic fox. Canad. J. Res., 5: 673-692.

—. 1942. Voles, mice and lemmings. Problems in population dynamics. Oxford: Clarendon Press. 496pp.

Ferenbaugh, Thomas L. 1916. A note concerning the occurrence of hydrophobia in the foxes of Alaska. Military Surgeon, 38:656-657.

Freuchen, Peter. 1935. Field notes and biological observations. Part II. In Report of the mammals collected by the Fifth Thule Expedition to arctic North America. Zoology I. By M. Degerb $\varnothing l$ and P. Freuchen. Rept. 5th Thule Exped. 1921-24, 2(4):1-278.

Gier, H. T. 1948. Rabies in the wild. J. Wildl. Mgmt., 12(2):142-153.

Habermann, Robert T., Carlton M. Herman, and Fletcher P. Williams, Jr. 1958. Distemper in raccoons and foxes suspected of having rabies. J. Amer. Vet. Med. Assoc., 132 (1) : $31-35$.

Helmboldt, C. F. and E. L. Jungherr. 1955. Distemper complex in wild carnivores simulating rabies. Amer. J. Vet. Res., 16(60):463469.

Miller, G. S. ANd R. Kellogg. 1955. List of North American recent mammals. U.S. Natl. Mus., Bull. No. 205. 954pp.

Murie, Adolph. 1944. The wolves of Mount McKinley. U.S. Dept. Interior, Natl. Park Serv., Fauna Ser. No. 5. 238pp.

Murie, Olaus J. 1936. Notes on the mammals of St. Lawrence Island, Alaska. Appendix III. In Archaeological excavations at Kukulik, St. Lawrence Island, Alaska. By O. W. Geist and F. G. Rainey. Univ. Alaska, Misc. Publ., Vol. 2. $391 \mathrm{pp}$.

Nelson, EdWARd W. 1887. Report upon natural history collections made in Alaska between the years 1877 and 1881. Wash., D.C.: U.S. Army, Signal Serv., Arctic Ser. No. 3. 337pp.

Pitelka, Frank A., P. Quentin ToMich, AND George W. Treichel. 1955. Ecological relations of jaegers and owls as lemming predators near Barrow, Alaska. Ecol. Monog., 25 (3) :85-117.

Plummer, P. J. G. 1947. Preliminary note on arctic dog disease and its relationship to rabies. Canad. J. Comp. Med., 11(6):154-160.

- 1947a. Further note on arctic dog disease and its relationship to rabies. Canad. J. Comp. Med., 11(11):330-334.

- 1954. Rabies in Canada, with reference to wildlife reservoirs. Bull. World Health Organization, 10:767-774.

Preble, Edward A. and W. L. McAtee. 1923. A biological survey of the Pribilof Islands, Alaska. U.S. Dept. Agric., N. Amer. Fauna No. 46. 255pp.

RAUSCH, RoBert. 1950. Observations on a cyclic decline of lemmings (Lemmus) on the arctic coast of Alaska during the spring of 1949. Arctic, 3(3):166-177.

-1 1951. Notes on the Nunamiut Eskimo and mammals of the Anaktuvuk Pass region, Brooks Range, Alaska. Arctic, 4(3):147-195.

-1953. On the status of some arctic mammals. Arctic, 6(2):91-148.

Reinhard, K. R., R. L. Rausch, and R. L. Gray. 1956. Field investigations of prophylaxis against epizootic distemper in arctic sled dogs. Proc. Book, Amer. Vet. Med. Assoc., 92nd Ann. Mtg., 1955. Pp.223-227.

Rhodes, A. J. and C. E. van Rooyen. 1953. Textbook of virology. Baltimore: Williams and Wilkins Co. 561pp.

Schiller, Everett L. and Robert Rausch. 1956. Mammals of the Katmai National Monument, Alaska. Arctic, 9(3):191-201.

SDoвnikov, V. M. 1935. Vzaimootnoshenia severnogo oleniia s zhivotnym mirom tundry i lesa. Vsesoiuznyi arkticheskii Institut. Trudy, 24: 5-66.

Thompson, Daniel Q. 1955. The 1953 lemming emigration at Point Barrow, Alaska. Arctic, 8(1):37-45.

WeLLS, K. F. 1957. The rabies menace in Canada. Canad. J. Public Health, 48:239-243.

Williams, Ralph B. 1949. Epizootic of rabies in interior Alaska 1945-47. Canad. J. Comp. Med., 13:136-143.

Received for publication February 10, 1958. 